\title{
HARVINAISESTA JA KIELLETYSTÄ TAVANOMAISEKSI JA HYVÄKSYTYKSI: MUUTTUVA KULTTUURINEN YMMÄRRYS AV(I)OEROSTA SUOMALAISESSA YHTEISKUNNASSA
}

\author{
Anna-Maija Castrén: VTT, apulaisprofessori, Itä-Suomen yliopisto \\ Hannele Forsberg: YTT, professori, Tampereen yliopisto \\ Aino Ritala-Koskinen: YTT, yliopistonlehtori, Tampereen yliopisto \\ anna-maïa.castren@uef.fi; hannele.forsberg@tuni.fi; aino.ritala-koskinen@tuni.fi
}

Janus vol. 27 (4) 2019, 344-361

\section{Tiivistelmä}

\section{of a ก U \&}

$\mathbf{\nabla}$

Paneudumme artikkelissa av(i)oeroa koskevan kulttuurisen ymmärryksen muutoksiin 1800-luvun lopulta tähän päivään: miten käsitys erosta on muuttunut ja miten muutos ilmenee suomalaisen yhteiskunnan pyrkimyksissä vastata liittojen purkautumiseen? Tarkastelemme eroa yhteiskunnallisten ja kulttuuristen tekijöiden, puhetapojen, poliittisten prosessien ja ihmisten toiminnan tuloksena kehkeytyvänä ilmiönä hyödyntäen kulttuuripolitiikan käsitettä. Huomioimme erojen yleisyyden,juridisen sääntelyn sekä sosiaalipolitiikan, sosiaalityön ja muun palvelujärjestelmän pyrkimykset vastata eroista aiheutuviksi nähtyihin ongelmiin. Jäsennämme muutosta kielletyn, torjuttavan ja hyväksyttävän eron termein. Käsitteellisellä tasolla avioeron kulttuurisessa ymmärryksessä tapahtuu siirtymä perheyksikön purkavasta ja yhteiskunnan kiinteyttä uhkaavasta avioerosta vanhempien parisuhdetta koskevaksi ratkaisuksi, jonka seurauksena lasten elämä järjestetään uudella tavalla. Suhtautuminen on muuttunut syyllisiä etsivästä sovinnolliseen eroon kannustavaksi: eroa pidetään nykyisin vaativana elämäntilanteen muutoksena, johon yhteiskunnan näkökulmasta sisältyy riskejä.

\section{JOHDANTO}

Avio- ja avoliittojen päättyminen eroon kiinnostaa tutkijoita monella tieteenalalla. Perheiden purkautuminen parisuhteiden päättyessä herättää tunteita myös laajemmin yhteiskunnassa ja tänä päivänä ollaan huolissaan erityisesti eron seurauksista lapsille.Vaikutusvaltaisin näkökulma eroihin liittyvissä kansainvälisissä tutkimuskeskusteluissa 1900- ja 2000-luvuilla on kytkeytynyt eron syihin ja seurauksiin (esim. Härkönen 2014). Tutkimuskirjallisuudessa on eritelty esimerkiksi väestötieteen näkökulmasta eron riskitekijöitä (esim. Jalovaara 2007; Mäenpää 2015) ja pureuduttu eron seurauksiin puolisoille ja lapsille (ks. yhteenveto kansainvälisestä tutkimuskirjallisuudesta Härkönen
2014). Tässä artikkelissa näkökulma on toinen. Kysymme, millaisten kulttuuristen prosessien kautta käsitys av(i)oerosta on muuttunut suomalaisessa yhteiskunnassa noin sadan vuoden ajanjaksolla 1800-luvun lopulta tähän päivään ja miten muutos ilmenee yhteiskunnan tavoissa reagoida liittojen purkautumiseen. Tarkastelua kehystää erojen vähittäinen yleistyminen, mutta huomiomme kohdistuu erityisesti siihen, miten eroista on eri aikoina keskusteltu ja millaisiin toimiin erojen on nähty yhteiskunnassa antavan aihetta.

Tarkoituksemme on lisätä ymmärrystä eroihin liitetyistä merkityksistä, joiden tunteminen auttaa hahmottamaan avioeroa moniulotteisena yhteiskunnallisena ja kulttuurisena kysymyksenä. 
Selkeyden vuoksi käytämme jatkossa ero-sanaa yleisterminä viittaamaan avio- ja avoeroihin.

Valtio vaikuttaa monin tavoin siihen, millainen ilmiö erosta yhteiskunnassa kehkeytyy. Lainsäädäntö linjaa ja uudistuksillaan muuttaa erokäytäntöjä sekä määrittelee eroa oikeudellisena prosessina. Laki ei kuitenkaan aina ole ensisijainen muutoksen airut vaan usein jo tapahtuneen asenne- ja käyttäytymisen muutoksen kirjaaja. Lailla myös säädetään yhteiskunnan tuesta ja valtio voi velvoittaa kunnat järjestämään palveluja. Tärkeä valtion vaikutustapa on eropalveluihin suunnattu välillinen tuki. Valtio rahoittaa nykyisin esimerkiksi Sosiaali- ja terveysjärjestöjen avustuskeskuksen (STEA) kautta laajasti kolmannen sektorin toimintaa ja projekteja, joissa kansalaisjärjestöt kehittävät ja tarjoavat palveluita eroperheille. Sosiaalipolitiikka ja sosiaalityö saavat eri aikoina erilaisia tehtäviä ja asemia yhteiskunnan eroon suhtautumisen prosesseissa.

\section{Avioeron kulttuUripolitilkka: KULTTUURINEN YMMÄRRYS AVIOEROSTA}

Lähestymistapamme on saanut vaikutteita Allison ja Adrian Jamesin (2004, 1-7;2008, 37-40) lapsuuden tutkimuksen yhteydessä hahmottelemasta kulttuuripolitiikan (cultural politics) käsitteestä. Kulttuuri ymmärretään tällöin laajasti (ks. Williams 1995) yhteiskunnassa ilmenevinä merkityksellistämisen ja ymmärtämisen tapoina ja käytäntöinä (James \& James 2004; 2008). Tutkijaparin viitoittamalla tavalla tarkastelemme avioeroa yhteiskunnallisten ja kulttuuristen tekijöiden, eri aikoina vallalla olevien puhetapojen, poliittisten ja lainsäädännöllisten prosessien ja tavallisten ihmisten perhe-elämää koskevan toiminnan ja erokäyttäytymisen tuloksena kehkeytyvänä, muuttuvana ilmiönä. Samalla jäljitämme eroon suhtautumisen painopistemuutoksia. Kulttuuripolitiikan käsite on suomeksi monimerkityksinen ja olemme päätyneet puhumaan yksinkertaisesti eroa koskevasta (kulttuurisesta) ymmärryksestä, (kulttuurisesta) suhtautumisesta eroon ja eroa koskevista (kulttuurisista) merkityksistä, viitaten niillä Jamesin ja Jamesin (mt.) kulttuuripolitiikan käsitteeseen.

Samantapaista lähestymistapaa on käyttänyt Pertti Alasuutari (2004) tarkastellessaan suomalaisen yhteiskunnan muutosta 1980-luvun suunnittelutaloudesta 2000-luvun kilpailutalouteen. Hän kohdistaa huomionsa muutoksen kulttuuriseen logiikkaan, sitä ilmentäviin puheavaruuksiin ja näiden institutionalisoitumiseen yhteiskunnallisessa ajassa ja ympäristössä. Alasuutari (mt.) hyödyntää julkisuuden puhetapojen ja niiden muutoksen tunnistamista, lainsäädännön muutoksia ilmentäviä valtiollisia asiakirjoja sekä ammattiryhmien keskinäistä julkista keskustelua. Myös hyvinvointivaltion kulttuurintutkimus (Autto \& Nygård 2015) tulee lähellä orientaatiotamme. Siinä hyvinvointivaltiota pyritään ymmärtämään ilmiönä, joka tuotetaan kulttuurin läpäisemässä vuorovaikutuksessa ihmisten $\mathrm{ja}$ muiden sosiaalisten toimijoiden välillä (mt., 10).

Kiinnitämme huomiota erityisesti niihin käännekohtiin, joissa erojen määrän kehityksessä on tapahtunut merkittäviä muutoksia. Erojen määrän kasvu 
tarkastelemallamme ajanjaksolla käy ilmi kuviosta 1. Lainsäädännön osalta olemme kiinnostuneita avioliittolakiin sisältyvistä eroamista koskevista säännöksistä ja näissä tapahtuneista muutoksista, samoin kuin näiden muutosten ympärillä käydyistä keskusteluista. Eroa koskevien säännösten ohella tarkastelemme lainsäädäntöä, jossa otetaan kantaa lapsen asemaan, huoltoon ja elatukseen sekä läheissuhteiden jatkuvuuteen vanhempien eron yhteydessä. Erityistä huomiota kiinnitämme sosiaalipolitiikan ja sosiaalityön pyrkimyksiin vastata avio- ja avoeroista aiheutuviksi nähtyihin ongelmiin. Hyödynnämme tarkastelussamme olemassa olevaa eri tieteenalojen tutkimuskirjallisuutta koskien avioliittoa, eroa ja lapsen asemaa sekä julkisia asiakirjoja (kuten mietintöjä, hallitusohjelmia, eduskunnan oikeusasiamiehen lausuntoja) ja kansalaisjärjestöjen materiaaleja. Systemaattisen lähiluvun tai analyysin sijaan pyrimme aineistomme pohjalta hahmottamaan avioeroa koskevassa kulttuurisessa ymmärryksessä tapahtuneita painopisteiden siirtymiä.

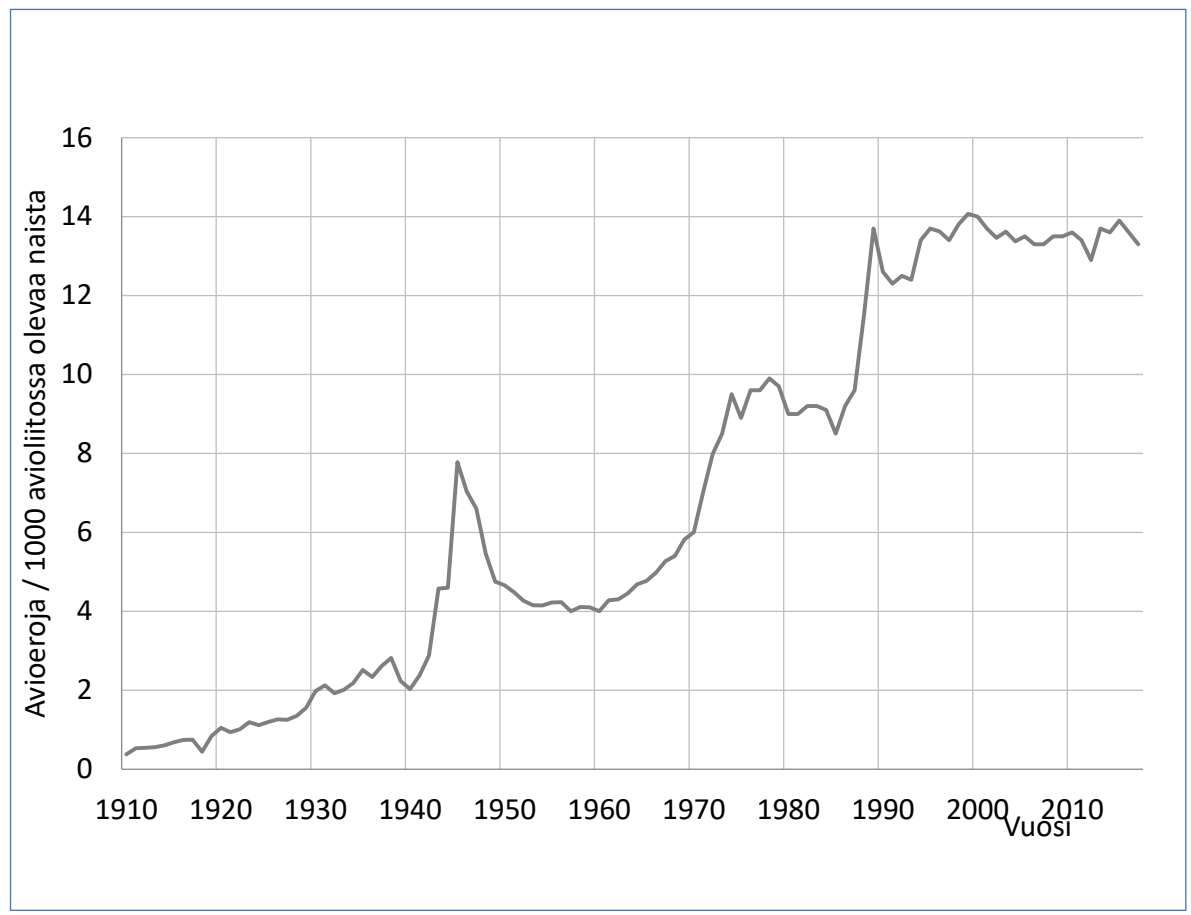

Kuvio 1. Avioerot Suomessa tuhatta naimisissa olevaa naista kohti vuosina 19102017 (Pitkänen \& Jalovaara 2007; Tilastokeskus väestönmuutostilastot) ${ }^{1}$ 
Eron ymmärtämisessä tapahtuneiden muutosten kannalta avioliiton ja perheen merkitys sosiaalisina instituutioina eri aikoina on tärkeä. Kehityskulkuja on tarkasteltava osana laajempia yhteiskunnallisia muutoksia yksilön ja yhteiskunnan välisessä suhteessa, perheiden rakenteessa, sukupuolten välisissä suhteissa ja lapsen asemassa (esim. Maksimainen 2010). Artikkelissa jäljitämme ajallista muutosta, jossa sekä avioliiton että perheen määrittelyssä rakenne on tehnyt tilaa sisällöille ja yhteiskunnallinen tehtävä yksilöllisille merkityksille. Avioliiton määrittelyssä tärkeäksi on tullut puolisoiden parisuhde ja perheessä moninaiset perhesidokset, jotka eivät välttämättä rajaudu kotitalouteen (esim. Forsberg \& Nätkin 2004; Maksimainen 2014; Yesilova 2009).

Tunnistamme tarkasteluajanjaksolla kolme erilaista suhtautumistapaa: (1) kielletty ero, jolloin eroaminen näyttäytyy uhkana yhteiskunnan kiinteydelle, (2) torjuttava ero, jolloin ero näyttäytyy yhteiskunnalle ja yksilölle haitallisena ja siksi torjuttavana sekä (3) hyväksytty ero, jolloin ero määrittyy yksilöllisenä parisuhteen purkavana elämänratkaisuna ja katse kääntyy ennen muuta lasten läheissuhteiden turvaamiseen. Suhtautumistavat ovat osittain limittäisiä ja monet kehitysprosessit kulkevat eritahtisesti. Tarkastelumme on väistämättä karkea yleiskuva sekä yritys hahmotella eroa koskevan kulttuuripolitiikan pitkää kaarta ja painopistesiirtymiä suomalaisessa yhteiskunnassa.

\section{KIELLETTY ERO - UHKA \\ YHTEISKUNNAN KIINTEYDELLE}

Avioliiton päättyminen viralliseen eroon oli Suomessa ennen 1900-lukua erittäin harvinaista. Avioliiton historiallisia muutoksia tutkineen Kari Pitkäsen (1986, 62) mukaan tätä ei tapahtunut juuri lainkaan; liitot olivat elinikäisiä ja päättyivät puolison kuolemaan. Välillä $1850-1870$ vuosittain vain noin $20-40$ avioliittoa päättyi eroon, kun taas kymmenisen tuhatta liittoa päättyi puolison kuolemaan. (Mt., 64; Pitkänen \& Jalovaara 2007, 149.) Eronneisuus lisääntyi jonkin verran 1800-luvun loppupuolella ja kasvu jatkui 1900-luvun alussa (Pitkänen 1986, 64; Pitkänen \& Jalovaara 2007, 149). Hyväksyttyjä syitä eroon olivat 1700-luvulta Ruotsin vallan ajalta periytyvän lainsäädännön mukaan aviorikos eli "huorin tekeminen" ja puolison hylkääminen, jotka olivat rangaistavia tekoja ja joihin tuli osoittaa syyllinen (Nieminen 1993, 75).

Avioerojen vähäisyys 1800-luvulla kytkeytyy avioliiton vahvaan asemaan yhteiskunnan suojelua nauttivana ytimenä eri puolilla Eurooppaa. Venäjän vallan alla kehkeytyvä suomalainen yhteiskunta imi vaikutteita Pohjoismaista ja manner-Euroopasta. (Esim. Jallinoja 1983.) 1800-loppupuolella muotoutumassa olevan sosiologian piirissä avioliitto nähtiin sopimuksena yhteiskunnan kanssa perheen perustamisesta, ei niinkään puolisoiden sopimuksena parisuhteesta. Näin myös ymmärrys erosta muotoutui suhteessa avioliittoon ja avioliittoperheen vahvaan asemaan 
yhteiskunnan keskeisenä sosiaalisena instituutiona. (Lamanna 2002, 140; Durkheim 1906, 12.) Suomessakin perhekysymykset kuuluivat julkisen huolen ja keskustelun piiriin; perhe ei ollut yksityisasia (Jallinoja 1983, 66). Vaikka kaikki 1800- ja 1900-luvun taitteessa avioitumisiässä olevat suomalaiset eivät avioituneet (Pitkänen \& Jalovaara 2007, 136), avioliitto oli uuden perheen syntymisen kannalta tärkeä sopimus. Ei-aviollinen yhteiselämä ei ollut tavatonta mutta sitä paheksuttiin erityisesti kirkon taholta (Jaakkola 1984) ja aviottomien lasten oikeudellinen asema oli heikko (Jousimaa 1983).

1800-luvun loppupuolella Euroopassa herättiin keskustelemaan myös sukupuolten tasa-arvosta ja avioeroista.Avioeroja tapahtui kaikkialla vähän, mutta suunta oli kasvava. (Esim. Ronfani 2003, 121-122.) Esimerkiksi Ranskassa käytiin pitkin 1800-lukua keskustelua avioerosta, jonka vallankumous oli tehnyt mahdolliseksi, mutta joka monarkian paluun seurauksena oli uudestaan hävitetty lainsäädännöstä vuonna 1814 . 1880-luvulla avioerosta tuli Ranskassa tietyin ehdoin mahdollista. (Lamanna 2002, 137-139.) Avioero oli myös se yhteiskunnallinen kiistakysymys, jota sosiologian klassikko Émile Durkheim kenties ahkerimmin kommentoi (Besnard 1993, 166). Durkheim ei vastustanut avioeroa sinänsä, mutta hän vastusti pyrkimyksï, joiden tarkoituksena oli helpottaa puolisoiden yhteisestä tahdosta tapahtuvaa liiton purkamista.Vaivattoman, yhteisestä suostumuksesta tapahtuvan avioeron pelättiin romuttavan avioliiton yhteiskuntaa kiinteyttävän ja vakauttavan vaikutuksen. (Lamanna 2002, 140; Durkheim 1906, 5.) 1800-luvun lopulla naisliike taisteli Pohjoismaissa naisten itsenäisemmän ja tasa-arvoisemman perhe-aseman puolesta. Naisia haluttiin vapauttaa "avioliiton pakosta" samalla kun alkoi yleistyä ajatus siitä, että avioliiton tuli perustua rakkauteen. (Jallinoja 1983, 57-60.) Suomalaiseen keskusteluun vaikutti laajasti tunnettu ruotsalainen naisasialiikkeen edustaja, Ellen Key (1849-1926), joka puolusti avioeron helpottamista osana rakkaudelle perustuvan avioliiton ohjelmaansa. Keyn näkemyksen mukaan ihmisellä oli velvollisuus onneen ja naisen elämässä tämä tarkoitti äitiyden ja eroottisen elämän tasapainoa. (Key 1903; Nieminen 1951, 168-181; Lähteenmäki 2000, 38-39.) Suomessa kristilliseen maailmankatsomukseen nojaava säätyyhteiskunta kyseenalaistui 1800- ja 1900-lukujen taitteessa ja uudenlaiset avioliittoa ja -eroa koskevat ajatukset levisivät erityisesti kaunokirjallisuuden ja varhaisen seksuaalivalistuskirjallisuuden avulla (Nieminen 1951, 29). Perhepolitiikan tutkija Armas Niemisen termein: absoluuttinen sukupuolimoraali sai rinnalleen relatiivisen sukupuolimoraalin sytykkeitä (mt.).

Tasa-arvoa ja hyvinvointia painottavat ideat sisällytettiin vähitellen lainsäädäntöön. Suomi seurasi muita Pohjoismaita lainsäädäntötyössä ja omaksui pohjoismaisen avioliittomallin (Pylkkänen 2012; Bradley 1996). Tämä erosi mannereurooppalaisista malleista siinä, että uskonnollisten ja kirkollisten korostusten sijaan avioliitto ja perhe yhdistettiin tasa-arvoa ja hyvinvointia koskeviin tavoitteisiin. Uusi avioliittolaki tuli voimaan vuonna 1929 ja irrotti avioliiton kirkon vaikutuspiiristä. Laki korosti puolisoiden tasa-arvoisuutta, yhteisvas- 
tuuta perheen elatuksesta ja sopimusvapautta. (Pylkkänen 2012.) Avioero oli mahdollinen mutta harvinainen, ja kuten muuallakin Euroopassa, eroon suhtauduttiin kielteisesti ja siihen tuli löytää syyllinen (Mahkonen 1980; Jaakkola 1984; Ronfani 2003).

Naisten ja miesten tasa-arvoa edistävällä vuoden 1929 lakiuudistuksella oli tärkeitä seurauksia lapsen asemalle erotilanteissa (Kurki-Suonio 1999, 368-375). Aiemmin vallalla olleesta edusmiehisyyden ajatuksesta, jonka perusteella vain isä oli huomioitu alaikäisen lapsen holhoojana, luovuttiin. Nainen alettiin nähdä luonnollisena kasvattajana, joten hänelle voitiin myös avioerotilanteessa myöntää oikeus toimia lastensa täysivaltaisena holhoojana. Lapsen eduksi alettiin tulkita nimenomaan äidin antama hoiva samalla kun isät erotettiin lasten huollosta (mt. 387390; ks. myös Yesilova 2009.) Huollon uskomisen vain toiselle vanhemmalle katsottiin toteuttavan parhaiten lapsen etua (Kurki-Suonio 1999, 358).

Vaikka lainsäädännön uudistamisessa huomioitiin lapset uudella tavalla, avioeroa pidettiin vielä vuosikymmenien ajan merkittävänä sosiaalisena ongelmana yhteiskuntatieteiden piirissä. Teollistuneissa yhteiskunnissa ydinperheen katsottiin eriytyneen muista sukulaisuuden sidoksista ja muodostaneen yksilön tärkeimmän sosiaalisen, emotionaalisen ja materiaalisen turvan lähteen, joten avioero aiheutti huomattavan uhan yksilöiden hyvinvoinnille ja yhteiskunnan sosiaaliselle vakaudelle: erot pirstoivat koteja ja jättivät ihmiset oman onnensa nojaan. (Goode 1961, 483; Burgess \& Locke 1945, 426, 622-625.)
Ei-aviollinen yhteiselämä eli nykykielellä avoliitot olivat Suomessa lailla kiellettyjä aina vuoteen 1926 saakka. Kuitenkin jo 1910- ja 1920-lukujen taitteesta alkaen tunnistettiin työväestön ja radikaalin sivistyneistön piirissä epävirallisia, vapaita toveri- ja vapaan rakkauden liittoja. 1930-luvulla nämä "susiparit" alettiin nähdä vakavana yhteiskunnan järjestystä ja moraalia eli avioliittoperustaisen ydinperheen asemaa horjuttavana yhteiskunnallisena ongelmana. (Jaakkola 1989, 116-120.)

1930-luvulla avioero liitettiin keskusteluun väestönkehityksestä ja se nähtiin uhkana hiipuvalle väestönkasvulle. Pohjoismaissa, Suomi mukaan lukien, alkoi tällöin kehkeytyä sosiaalipolitiikan uusi lohko, perhepolitiikka. Tässä prosessissa ruotsalaisten sosiaalipolitiikan tutkijoiden Alva (1902-1986) ja Gunnar Myrdalin (1898-1987) väestökriisiä koskeva keskustelu oli tärkeässä roolissa (Nieminen 1956, 93). Valtio alkoi kehittää ja myöntää taloudellista tukea syntyvistä lapsista ja siten kannustaa lasten synnyttämiseen. Taloudellisten näkökohtien ohella alettiin sittemmin vaatia huomion kiinnittämistä myös avioliittokäsityksiin ja puolisoiden keskinäiseen suhteeseen (Nieminen 1951, $1-2)$.

Vaatimusten taustalla oli avioliittokäsityksen muutos. Amerikkalaiset sosiologit kiinnittivät 1940-luvulla huomiota avioliiton muuttumiseen sosiaalisesta instituutiosta kumppanuussuhteeksi. Tämä toi uuden näkökulman myös liiton purkautumiseen. Puolisoiden huonot välit, riidat ja väkivalta synnyttivät tilanteita, joissa perheenä eläminen ei palvellut enää tarkoitustaan ja jotka olivat haitallisia kaikille osapuolille. (Bur- 
gess \& Locke 1945.) Suhteiden laatuun kohdistuva mielenkiinto ilmensi laajempaa siirtymää avioeroa koskevassa ymmärryksessä: 1900-luvun puoliväliin tultaessa huolen painopiste alkoi siirtyä yhteiskunnallisen koheesion ja sukupuolimoraalin rapautumisesta parisuhteen tukemiseen ristiriitojen ilmaantuessa tai niiden varalta sekä avioerolasten asemaan.

\section{TORJUTTAVA ERO - HAITALLINEN YHTEISKUNNALLE JA YKSILÖLLE}

Sotien jälkeinen siirtymä agraarimaailmasta kohti liberaalimpaa ja urbaanimpaa yhteiskuntaa ja siihen kietoutuva arvojen muutos näkyi avioerojen määrän lisääntymisessä. Yhteiskunnallisessa keskustelussa avioerojen määrän kasvun nähtiin uhkaavan avioliittoa ja perhettä yhteiskunnallisina instituutioina (Nieminen 1951, 29). Vielä pitkään yhteiskunnan hallitseva ihanne korosti eliniäksi solmitun avioliittoperheen ensisijaisuutta, erityisesti jos parilla oli lapsia. Siksi avioero koettiin myös yksilötasolla usein tappiona ja häpeänä, joka pyrittiin salaamaan. (Hemminki 2010, 78.)

Toisen maailmansodan jälkeen avioerot alkoivat yleistyä Suomessa. Ennen 1980-lukua erojen määrässä voidaan erottaa kaksi kasvupiikkiä: sotaa seuranneet poikkeuksellisen runsaan eronneisuuden vuodet 1940-luvulla ja 1970-luvun kiivas erojen määrän kasvu. (Ks. Kuvio 1; Pitkänen \& Jalovaara 2007.)

Sota-aikana elämän pysyvyyden kyseenalaistuminen ja kuoleman läsnäolo näkyivät muun muassa päihteiden käy- tön ja lyhytaikaisten suhteiden lisääntymisenä, millä oli yhteys myöhemmin avioeroihin. Sota-aikana myös solmittiin "pika-avioliittoja", jotka sittemmin purkautuivat herkästi. Sota muutti naisten asemaa itsenäisemmäksi, mikä saattoi kasvattaa rohkeutta irtaantua epätyydyttävästä avioliitosta. Taustalla oli myös sukupuoli- ja seksuaalimoraalin muuttuminen, erityisesti avioliiton merkityksen muutos yhä laajemmin rakkaudelle perustuvaksi kumppanuussuhteeksi. (Näre 2008.)

Avioerojen lisääntyminen synnytti niitä ehkäisemään pyrkivän avioliitto- ja perheneuvonnan. Tampereen Kaupunkilähetyksen pappi Matti Joensuu aloitti neuvonnan kesällä 1944 ja saman vuoden marraskuussa julkaistiin Aamulehdessä kuuluisa ilmoitus otsikolla "Älkää ottako avioeroa!",jossa tarjottiin ilmaista apua vaikeuksiin. Tätä ilmoitusta voi pitää kirkon avioliittoneuvonnan alkuna. (Kulhia 2012, 58-61.) 1940-luvulta alkaen psykotieteiden piirissä virinneet perhekasvatuksen ja -neuvonnan ideat alkoivat rantautua myös Suomeen. Kirkon ohella erityisesti Väestöliiton avioliittoneuvolatoiminta (1941 alkaen) ja Mannerheimin lastensuojeluliiton toimintana alkanut kasvatusneuvolatyö (1940-luvulla) ilmensivät näitä pyrkimyksiä. Uusi idea oli tarjota ennaltaehkäisevää keskusteluapua ristiriitoihin ajautuneille pariskunnille. Yhteiskunnallisessa keskustelussa ilmennyt huoli avioliittoinstituution kyseenalaistumisesta sekä aviottomien lasten määrän lisääntymisestä ja heikosta asemasta oli keskeinen toiminnan motiivi. (Nieminen 1956, 33, 71, 313.) Kasvaakseen onnellisena ja kehittyäkseen tasapainoiseksi aikuiseksi lapsen ajateltiin tarvitsevan yhden kodin ja kaksi vanhempaa 
(esim. Goode 1961, 548-550). Toisen maailmansodan jälkeen sosiaalipolitiikka omaksui monissa maissa perhettä tukevan ja "sen menestystä edistävän" luonteen (Nieminen 1951, 313). Taustalla oli ajatus perheen hyvän ja lapsen hyvän yhdistymisestä (mt., 71). Perhepolitiikan tavoitteena oli tehdä perhe entistä kykenevämmäksi täyttämään tehtävänsä ja kaikki tähän liittyvät toimenpiteet oli nähtävä tehokkaana ennaltaehkäisevänä huoltona, joka vähensi tarvetta sosiaalihuollon toimiin. (Nieminen 1956, 33.)

Vuoden 1948 avioliittolain uudistuksessa eron myöntämisen perusteeksi otettiin mukaan asumuseroa koskeva säännöstö. Avioeron myöntäminen tuli siten mahdolliseksi asumuseron kautta ilman että tarvittiin näyttöä toisen osapuolen syyllisyydestä. Puolisoita velvoitettiin kuitenkin sovitteluun, jossa jäljitettiin yhteiselämän jatkamisen mahdollisuuksia. Lapsen edun korostumisen seurauksena vanhemman sopivuudesta lapsen huoltajaksi kehkeytyi syyllisyyttä olennaisempi perusta erottaessa. Lapsen huollosta erotetun vanhemman oikeus tavata lastaan (ns. tapaamisoikeus) muotoutui käytännöksi 1940-luvun kuluessa, mutta varsinainen tapaamisoikeuden sääntely antoi odottaa itseään 1970-luvulle. (KurkiSuonio 1999, 393-408; Laki avioliittolain muuttamisesta 681/1948.)

1950-luvulla yhteiskunnallisessa keskustelussa vahvistuivat edelleen ajatukset ehjästä, hyvin toimivasta ydinperheestä lapsen hyvän elämän takeena (Yesilova 2009). Ammattilaiset toivat esiin, että avioliittoristiriitoihin tulisi saada ennaltaehkäisevää keskusteluapua jopa sosiaalitoimistosta, vaikka lainsäädäntö ei tähän velvoittanutkaan (ks. Nieminen 1951, 6).Ymmärrykseen erosta alkoi vaikuttaa myös amerikkalaisen kriminologian piirissä kehkeytynyt tulkintasuunta, jossa osoitettiin avioero keskeiseksi syyksi nuorten rikolliseen käyttäytymisen (esim. Monahan 1957; ks. myös Levin 2004, 15). Havainto vahvisti avioerojen ennaltaehkäisyn tärkeyttä. Eronneet perheet lapsineen saivat herkästi "vajaaperheen" ja "avioerolapsen" leimoja. Esimerkiksi Armas Nieminen kirjoitti vuonna 1956 seuraavasti: "...monilukuiset tutkimukset ovat yhtäpitävästi osoittaneet, että ihmisen todennäköisyys tulla yhteiskuntaan sopeutumattomaksi kansalaiseksi on monin verroin suurempi jos hän on kasvanut vaillinaisessa perheessä...kuin jos hän on kasvanut sisäisesti hyvin organisoituneessa perheessä." (Nieminen 1956, 26.) Norjalainen lasten erokokemuksia tutkinut Irene Levin $(2004,15)$ kuitenkin muistuttaa, että amerikkalaiset tutkimukset tehtiin aikana, jolloin erot olivat hyvin harvinaisia ja vahvasti stigmatisoituja.

Toinen erojen määrän nopean kasvun kausi ja asettuminen uudelle tasolle osui 1970-luvulle. Tähän mennessä yhteiskunnallinen ilmapiiri oli muuttunut monessa mielessä sotien nostattamaan avioeroaaltoon verrattuna. 1960-luvun kulttuurinen murros näytti suuntaa kaupungistuvan yhteiskunnan vapaamielistymiselle ja tasa-arvoistumiselle. Siihen liittyivät sukupuolimoraalin murros, ehkäisypilleri, naisen aseman muuttuminen, työssäkäynnin yleistyminen ja avoliittojen yleistyminen, jotka väistämättä heijastuivat avioeroon suhtautumiseen. (Jallinoja 1984, 76-88.) 
Avioliittolain uudistamiseen tähtäävä komiteanmietintö vuodelta 1972 ilmentää suhtautumistavoissa tapahtuneita muutoksia (Avioliittolakikomitean mietintö 1972). Keskeisenä ajatuksena mietinnössä oli ymmärrys avioliitosta kahden tasavertaisen ihmisen välisenä, keskinäiseen kiintymykseen perustuvana vapaaehtoisena yhteiselämän muotona. Komitean mielestä yhteiskunnan ei tullut asettaa esteitä avioliiton purkamiselle eikä myöskään eroon johtaneilla seikoilla ollut merkitystä. Näin myöskään syyllisyyden tai välien rikkoutumisen selvittämiselle tuomioistuimessa ei katsottu olevan tarvetta. (Mt.) Tämä näkemys kohtasi kuitenkin jyrkkää vastustusta. Avioliittolakikomitea itsessään oli näkemyksistä erimielinen ja lausuntokierroksella mietintö sai varsin ristiriitaisen vastaanoton. Vahva näkemys oli, että yhteiskunnan velvollisuutena on vastustaa harkitsemattomia ja ilman perusteita haettavia eroja. (Jaakkola 1975, 33-38.)

Tasa-arvoistumisen tuulet näkyivät myös lapsen aseman muutoksina. 1970-luvulla puhuttiin yleisesti avioerolapsista, jotka herkästi samaistettiin "ongelmalapsiksi" tulkitsemalla esimerkiksi lapsen käyttäytymisen ongelmat tai koulunkäyntiin liittyvät vaikeudet osoittimiksi avioeron negatiivisista vaikutuksista (esim. Hemminki 2010). Lasten oikeudellinen asema muuttui kuitenkin pian ratkaisevasti tasa-arvoisempaan suuntaan. 1970-luvun alussa aloitettu ja 1976 voimaan astunut, lasten asemaa lainsäädännössä uudistava niin sanottu lapsipaketti uudisti isyyslain (700/1975), lain lapsen elatuksesta (704/1975), perintökaaren (710/1975), avioliittolain (705/1975) ja holhouslain (711/1975) niin, että kaikki lapset syn- typerästä tai perhe-asemasta riippumatta saivat oikeudellisen tasa-arvon. Taustalla oli kansainvälisen lapsen asemaa koskevan YK:n Lapsen oikeuksien julistuksen (1959) hengen toteuttaminen, jolle suomalaista yhteiskuntaa monin tavoin uudistanut 1960-luvun kulttuurinen murros tarjosi siivet. (Satka ym. 2002, 245-250.)

Lapsen aseman muutokset välittyivät myös tapaan, jolla avioero ymmärrettiin. Esimerkiksi eroavien parien lasten asema mainitaan ensimmäisen kerran sovittelun aiheena vuoden 1963 avioliittolain muutoksessa (Laki avioliittolain muuttamisesta 342/1963) ja Oikeusministeriön yleiskirjeessä (Asumuserosovittelu 1963). Jatkossa avioero muuttui aiempaa tavanomaisemmaksi ja hyväksytymmäksi tapahtumaksi.

\section{HYVÄKSYTTY ERO - YKSILÖLLINEN PARISUHTEEN PURKAVA ELÄMÄNRATKAISU}

1960-luvulla käynnistynyt moninainen kulttuurinen murros loi pohjaa avioeron tavanomaistumiselle nimenomaan parisuhdetta koskevana ratkaisuna 1980-luvulla. Kyse oli erojen aiempaa laajemmasta hyväksymisestä ja kehityskulusta, jossa parisuhteen laadusta tuli merkittävämpää kuin liiton kestävyydestä; huonoa suhdetta ei ollut tarvetta ylläpitää muodon vuoksi (Maksimainen 2014). Yhteiskunnassa vakiintui uudenlainen suhtautumistapa eroon ja siitä seuraaviin perhejärjestelyihin. Avioeroihin alettiin rinnastaa myös avoparien erot, etenkin niissä tilanteissa, joissa parilla oli yhteisiä lapsia. 1980- ja 1990-lukuja voi luonnehtia eräänlaisena avioeroihin sopeutumisen ja tämän sopeutumisen yhteiskunnal- 
lisen institutionalisoitumisen aikana. 2000-luvulla alettiin etsiä uudenlaista suhdetta ennen kaikkea eron jälkeiseen perhe-elämään. Brittiläinen perhetutkija Carol Smart (2000) analysoi tätä laajemminkin tunnistettua tavanomaistumisen käännettä esittämällä, että ero heijastaa pikemminkin moraalikäytäntöjen muuttumista kuin moraalin heikkenemistä yksilöiden, perheiden ja laajemman yhteiskunnan tasolla.

Suomessa avioerojen määrissä tapahtui kasvupyrähdys vuonna 1988 voimaan astuneen lakiuudistuksen (Laki avioliittolain muuttamisesta 411/1987) jälkeen. Avioerojen määrä nousi 13 000-14 000 vuositasolle ja on pysynyt siinä viimeiset 30 vuotta. (SVT: Siviilisäädyn muutokset 2016.) Samaan aikaan myös avoliittojen määrä lapsiperheiden perhemuotona kasvoi voimakkaasti (SVT: Perheet 2018). 1990-luvun loppupuolella arvioitiin, että avoliittoja päätyy eroon avioeroihin nähden noin kaksinkertainen määrä (Nikander 1996; 1997) ja 2010-luvulla avoerojen määrän arvioidaan vielä selkeästi kasvaneen 1990-luvun puolivälistä (SVT: Perheet 2013). Avoliitosta eroamisen nostaminen osaksi eronneisuuden tilastollista tarkastelua viestii osaltaan siitä, että yhteiskunnan tasolla ero nähdään ennen kaikkea parisuhteen purkautumisena ja siitä seuraavina ratkaistavina kysymyksinä - varsinkin kun liitosta on lapsia.

Eräs merkittävä demografinen piirre on, että ihmiset päätyvät eroon aina vain lyhyemmän liiton jälkeen. Avioliittokohorteittainen eronneisuuden tarkastelu tuo esiin, että mitä myöhempi on avioliiton solmimisvuosi, sitä nopeammin parit päätyvät eroon (SVT: Väestö 2017). Myös iäkkäimpien, yli 50-vuo- tiaiden eronneisuudessa on tapahtunut selkeää kasvua 2000-luvun alkuvuosina (Tilastokeskus: Avioeronneisuus... 1990-2017). Eroamisesta on siis tullut yleisempää kaikissa ikäryhmissä.

Avioliittolain uudistus pääsi etenemään 1980-luvulla. Keskeiseltä sisällöltään vuoden 1972 avioliittolakikomitean ehdotuksen mukainen uusi laki astui voimaan vuoden 1988 alusta (Litmala 2001). Laki vahvisti avioeron yhteiskunnallisen normalisoitumisen prosessia, sillä eron saamiseksi ei enää edellytetty mitään perustetta, vaan siitä tuli riita-asian ja syyllisyyden osoittamisen sijaan hakemus- ja ilmoitusasia. Samalla päätös erosta siirtyi yhteiskunnalta yksilöille, vaikka avioliiton purkaminen juridisena sopimuksena vaatiikin tuomioistuimen päätöksen. (Laki avioliittolain muuttamisesta 411/1987.)

Uudistettuun avioliittolakiin sisällytettiin säädökset perheasioiden sovittelusta ja sen sisällöstä (Laki avioliittolain... 411/1987, 5. luku). Sovittelun tarkoitukseksi tuli tarjota ihmisille päätöksenteon välineitä, ei niinkään aiemman pakollisen asumuserosovittelun tapaan pyrkiä ensisijaisesti pitämään avioliittoa koossa. (Taskinen 1993; 1994.) Sovittelulla pyrittiin lieventämään vapaamielisen avioliittolain mahdollisia kielteisiä seurauksia (Antikainen ym. 2009, 195). Käytännössä perheasioiden sovittelu jäi pitkäksi ajaksi varsin näkymättömäksi palveluksi.

Erojen tavallistumisen seurauksena yhteiskunnallinen keskustelu siirtyi eroamisen tapaan ja siihen, miten ero voitaisiin hoitaa mahdollisimman vähin vaurioin. Erosta tuli eräänlainen "emotionaalinen selviytymiskamppai- 
lu" (Maksimainen 2014), mutta yhteiskunnan näkökulmaa määritti vahvasti lapsen edun periaate, jolloin oleellista oli perhesuhteiden laatu eron jälkeen ja lapsen vanhemmuussuhteiden jatkuvuus. Yhteishuollosta tuli tavoiteltava ideaali, johon vanhempia haluttiin ohjata, ja yhteishuoltosopimukseen pääsemisestä keskeinen tavoite (Antikainen ym. 2009, 195-196). Jo ennen avioliittolain uudistusta laki lapsen huollosta ja tapaamisoikeudesta (361/1983) oli uudistanut suhtautumista vanhemmuuteen sekä lapsen ja vanhemman suhteeseen avo- ja avioerossa. Laki toi vahvana esiin ajatuksen suhteen jatkuvuuden tärkeydestä. Tapaamisoikeus kääntyi nyt lapsen oikeudeksi tavata erillään asuvaa vanhempaansa eron jälkeen. Lapset jäivät useimmiten asumaan äidin kanssa, mutta käytännöksi muotoutui, että isää tavataan vähintään joka toinen viikonloppu ja loma-aikoina. Uudella tavalla ajattelevat vanhemmat alkoivat jakaa lastensa asumista vuorottaisesti. (Panttila 2005.) Samalla lapsista tuli tärkeitä perhesuhteiden jatkuvuuden symboleja myös eronneille isille. Vanhempien liitto ja parisuhde saattoivat päättyä, mutta perhe-elämä jatkui vanhemman ja lapsen suhteen vaalimisen kautta (Théry 1986; Smart \& Neale 1999). Perheyksikkö-ajattelusta siirryttiin viimeistään tässä vaiheessa perheenjäsenten välisten suhteiden merkityksen korostamiseen. Lapsesta tuli lähes aikuisiin rinnastettava perheenjäsen. (Esim. Nätkin 2004.)

Koska eroamisessa korostettiin perheenjäsenten välisten suhteiden jatkuvuutta, paine palveluiden kehittämiseen kasvoi. Parisuhdepalvelujen kenttä on kuitenkin nykyisin hajanainen ja vastaa melko heikosti ihmisten tarpei- siin (Paajanen 2003, 51-64; ks. myös Haavisto ym. 2014, 12-13; EOA 2004). Palveluita tarjoavat kunnallisten ja yksityisten toimijoiden ohella myös kirkko, järjestöt ja yhdistykset (ks. Maksimainen 2014). Perheasioiden sovittelu säädettiin sosiaalihuoltolain mukaiseksi sosiaalipalveluksi, jota kunnan sosiaalilautakunnan on järjestettävä kunnan omana tai muualta hankittavana palveluna (Sosiaalihuoltolaki 1301/2014, \$14). Erityisesti järjestökenttä on ollut aktiivinen eropalvelujen kehittämisessä (ks. Nurmela ja Kaittila tässä numerossa). Miessakit ry:n Erosta Elossa -palvelu tukee miehiä ero-ongelmien käsittelyssä tavoitteenaan turvata lapsen ja isän suhteen jatkuminen eron jälkeen (Miessakit 2018). Ensi- ja turvakotien liitto kehitti vuosituhannen alussa valvottujen tapaamisten toimintamallia lapsille, joiden vanhemmat olivat eronneet väkivaltaisesta parisuhteesta ja lapsen ja vanhemman tapaaminen oli määrätty valvonnassa tapahtuvaksi (Kalavainen 2004). Eläkeliitto on järjestänyt sopeutumiskursseja iäkkäille eronneille 2000-luvun alkupuolelta lähtien (Eläkeliitto 2019). 2010-luvulla Ensi- ja turvakotien liiton kehittämistyössä on panostettu vanhempien vertaistukeen, eroneuvontaan ja paikkakuntakohtaisia eropalveluja koskevan tiedon kokoamiseen. Myös Lastensuojelun keskusliitto ja Mannerheimin lastensuojeluliitto ovat olleet aktiivisia palveluiden kehittämisessä, mistä esimerkkinä ovat tapaamispaikat lapsille ja vanhemmille, jotka eivät voi tavata etävanhemman luona. Järjestöt ovat kehittäneet myös verkkopalveluja erokysymysten kanssa painiskelevien tueksi. (Apuaeroon.fi 2018; MLL Tampereen osaston... 2018.) 
Oma tematiikkansa liittyy huolto- ja tapaamisriitoihin, joita puidaan tuomioistuimissa. Tällöin käräjäoikeudet pyytävät sosiaalitoimelta olosuhdeselvityksiä lasten huollosta ja asumisesta päättämiseksi. (Forsberg ym. 2018; Lastensuojelun käsikirja 2018; ks. Kääriäinen tässä numerossa.) Tuomioistuimien sisään on kehitetty 2010-luvun alussa oma asiantuntija-avusteinen huoltoriitojen sovittelumenettely, jossa tavoitteena on päästä sovintoon ja luopua oikeudenkäynnistä. Sovittelua toteutetaan moniammatillisena tuomareiden ja asiaan perehtyneen psykologi-, sosiaalityöntekijä- tai lastenpsykiatriasiantuntija-avustajan yhteistyönä. (Asiantuntija-avusteinen huoltoriitojen sovittelu... 2014.)

Kolmessa viimeisessä hallitusohjelmassa lasten ja perheiden hyvinvoinnin kysymykset ovat olleet vahvasti esillä. Eropalvelujen osalta on pyritty edelleen kehittämään sovittelua (Pääministeri Jyrki Kataisen... 2011), vahvistamaan eropalveluita osana lapsi- ja perhepalveluiden kokonaisuudistusta ja uudistamaan lapsen huolto- ja tapaamisoikeuslainsäädäntö (Pääministeri Juha Sipilän...2015). Eropalveluja kehittäviä hankkeita onkin käynnistynyt ja ne ovat koonneet yhteen kunta- ja järjestötoimijoita. Informaation antaminen, tuen saaminen, palveluiden löytyminen ja työskentely kohti sovinnollista eroa ovat nousseet eri toimijoiden yhteiseksi asiaksi. (Esim. MLL Tampereen osaston Eron ensiapupiste 2018.) Osana kehittämistyötä sosiaali- ja terveysministeriö on julkaissut oppaan lapsen arjen järjestämisestä eron jälkeen, sekä tähän liittyvän materiaalin vanhemmuussuunnitelman laatimiseksi (Vanhemmuussuunni- telmasta tukea... 2018). Viimeisimmässä pääministeri Antti Rinteen hallitusohjelmassa asetetaan tavoitteeksi edistää vuoroviikkoasumista koskevan selvityksen toimenpide-ehdotuksia (2019, 145), jotka koskevat ennen muuta sosiaaliturvaa ja palveluita (Ilmonen ym. 2018).

Viimeisin lapsen huoltoa ja tapaamista koskevan lain muutos (Laki lapsen... 190/2019; ks. Koulu tässä numerossa) astuu voimaan joulukuussa 2019. Uudistetussa laissa korostuu eronjälkeisen perhe-elämän säätely. Käytäntönä yleistynyt lasten vuorottainen asuminen vanhempiensa kanssa on otettu lakiin lasten asumisratkaisujen yhdeksi vaihtoehdoksi. Kun eron jälkeinen yhteistyö vanhempien kesken oli pitkään ajatuksena outo sekä kulttuurisesti että yksilöllisellä tasolla (esim. Théry 1986; Smart 2000), pyritään nyt vahvistamaan tapoja ja normeja tämän yhteistyön vakiinnuttamiseen. Eron jälkeisen yhteistyövanhemmuuden institutionalisoituminen suomalaisessa yhteiskunnassa siis syvenee. Erityinen uutuus laissa on tapaamisoikeuden laajentaminen niin, että lapselle voidaan tuomioistuimen päätöksellä vahvistaa oikeus tavata eron jälkeen hänelle erityisen läheistä henkilöä, kuten iso- tai sijaisvanhempaa tai vanhemman entistä puolisoa. Taustalla on ajatus lasten elettyjen perhesuhteiden moninaistumisesta (esim. sateenkaari-, uus- ja sijaisperheet) ja tärkeiden suhteiden jatkuvuuden tukemisesta eron tai kuolemantapauksen sattuessa.

\section{LOPUKSI}

Olemme artikkelissa hahmotelleet eron kulttuurisen ymmärryksen pitkää kaar- 
ta Suomessa ja tarkastelleet osin eritahtisia mutta keskenään limittyviä prosesseja, joiden vaikutuksesta kielletystä ja torjutusta erosta on tullut hyväksytty. Tarkastelujakson alussa 1800-luvun lopulla ero nähtiin yhteiskunnan koheesiota perustavalla tavalla uhkaavana ongelmana. Perhe oli yhteiskunnan perusyksikkö, jonka tehtävänä oli huolehtia väestön uusiutumisesta, sosialisaatiosta ja välttämättömien elämän edellytysten tarjoamisesta. Tämä lisäsi avioliiton arvostusta samalla kun naimattomuus näyttäytyi "luonnottomana" (Nieminen 1993, 7). 2000-luvun Suomessa avioliitto on korkeasta eronneisuudesta huolimatta edelleen tärkeä instituutio, mutta naimattomuutta ei voi pitää epätarkoituksenmukaisena, sillä lapsia syntyy myös muihin kuin heteroaikuisten avioliittoperheisiin (ks. Castrén ym. 2017).

Tarkastelujaksolla tapahtui käsitteellisellä tasolla siirtymä perheyksikön purkavasta ja yhteiskunnallista kiinteyttä uhkaavasta kielletystä avioerosta vanhempien parisuhdetta koskevaksi hyväksytyksi ratkaisuksi, jonka seurauksena erityisesti lasten elämä tulee järjestää uudella tavalla. Nykykeskustelussa ei pohdita eron sosiaalista hyväksyttävyyttä, vaan kannustetaan sen terapeuttiseen hallintaan (Maksimainen 2010, 77) ja vaaditaan lapsille aiheutuvien haittojen minimoimista.

Eroon suhtaudutaan kuitenkin edelleen normatiivisesti. Vaikka sitä ei enää pidetä osoituksena moraalisesta rappiosta eikä se ole aikuisia ja lapsia leimaava häpeätahra, normatiivisuus kohdistuu eroamisen tapaan: aikuisten tulee osata erota oikein. Tavoitteena on "hyvä ero" tai "sovinnollinen ero", jossa vanhempien yhteistyö ja kasvatusvastuun jakaminen jatkuvat liiton päättymisen jälkeenkin.

Kokoavasti toteamme, että tämän päivän Suomessa ero ymmärretään lähinnä kolmella ulottuvuudella. Ensisijaisesti ero on aikuisten parisuhdetta koskeva ratkaisu. Koska avioliitto saa merkityksensä parisuhteena, ero on ratkaisu ongelmaan, jos suhde ei ole tyydyttävä. Moraalinen tuomittavuus on liudentunut eron ympäriltä. (Maksimainen 2010; 2014.) Toiseksi ero ymmärretään kuin minkä tahansa taloudellis-oikeudellisen sopimuksen purkautuminen, josta seuraa oikeudellisten suhteiden ja vastuiden uudelleen järjestelyä (esim. Pylkkänen 2012). Tällainen on muun muassa omaisuuden jako, mutta erityisen kiinnostunut yhteiskunta on lasten huollon ja elatuksen järjestämisestä (ks. Haapanen \& Hakovirta tässä numerossa). Kolmanneksi ero on haaste palvelujärjestelmälle, jonka tehtävänä on minimoida osallisille koituvia haittoja ja tukea erityisesti lapsia vanhempien parisuhteen päättyessä (esim. Antikainen ym. 2009).

Sosiaalipolitiikan ja sosiaalityön painopiste eroihin liittyen on tänä päivänä tiukasti kiinni lasten elämän tukemisessa. Voimavaroja kohdistetaan eropalvelujen saatavuuteen ennaltaehkäisyn mielessä. Myös vaikeiden erokonfliktien keskelle jääneiden lasten elämän edellytyksiä pyritään turvaamaan. Kiinnostavaa on, että päätään on nostanut riskiajattelu, esimerkiksi tutkimuksellinen huomio vanhempien eron ja lastensuojelutoimien yhteyksistä (Kestilä ym. 2012; Ristikari ym. 2018, 79). Lapsi- ja perhepalveluiden muutosoh- 
jelmaa (LAPE) voidaan pitää osaltaan osoituksena siitä, että muutaman vuosikymmenen tauon jälkeen myös valtio on palaamassa aktiiviseksi toimijaksi eroon liittyvissä kysymyksissä (ks. esim. Bildjuschkin 2018).

Monet tulevaisuudessa yhä tärkeämmiksi muodostuvat teemat eron kulttuurisessa ymmärryksessä ovat rajautuneet tarkastelumme ulkopuolelle. Yksi näistä liittyy liittojen kansainvälistymiseen ja yhteiskunnan kulttuurisen moninaisuuden kasvuun. Sosiaalipoliittisen ohjauksen ja sosiaalityön on jatkossa herkistyttävä erilaisista kulttuurisista ja uskonnollisista taustoista lähtöisin olevien ihmisten käsityksille (esim. AlSharmani ym. 2018). Toinen tulevaisuuden teema on eletyn vanhemmuuden nousu biologisen rinnalle lapsen perhe- ja läheissuhteiden kriteerinä erojen jälkeen. Erityisesti seksuaali- ja sukupuolivähemmistöihin kuuluvien vanhempien ja lasten muodostamien perheiden vanhemmuusjärjestelyt virittävät tällaisia näkymiä.

\section{VIITE}

${ }^{1}$ Kiitämme Marika Jalovaaraa kuvion päivittämisestä kattamaan myös vuodet 2006 2017.

\section{KirjallisuUs}

Alasuutari, Pertti (2004) Suunnittelutaloudesta kilpailutalouteen. Miten muutos oli ideologisesti mahdollinen? Yhteiskuntapolitiikka 69 (1), 3-16.

Al-Sharmani, Mulki \& Mustasaari, Sanna \& Ismail, Abdirashid (2018) Uskonnollinen perheriitojen sovittelu suomalaisissa moskeijoissa: kehittyviä rooleja ja muo- vautuvia käytäntöjä. Teoksessa Johanna Hiitola, Merja Anis \& Kati Turtiainen (toim.) Maahanmuutto, palvelut ja hyvinvointi. Kohtaamisissa kehittyviä käytäntöjä. Tampere:Vastapaino, 53-75.

Antikainen, Mari \& Hämäläinen, Juha \& Pölkki, Pirjo (2009) Sosiaalityöntekijän asiantuntijuus lapsen huolto- ja tapaamissopimuspalvelussa. Teoksessa Aino Kääriäinen, Juha Hämäläinen \& Pirjo Pölkki (toim.) Ero, vanhemmuus ja tukeminen. Helsinki: Lastensuojelun Keskusliitto, 194-223.

Asiantuntija-avusteinen huoltoriitojen sovittelu tuomioistuimessa tulee valtakunnalliseksi (2014) Oikeusministeriö. https://oikeus.fi/fi/index/ ajankohtaista/tiedotteet/2014/04/asiantuntija-avusteinenhuoltoriitojensovittelutuomioistuimessatuleevaltakunnalliseksi.html Luettu 7.12.2018.

Asumuserosovittelu 1963. Oikeusministeriön yleiskirje 2/341, 1963. Helsinki: Oikeusministeriö.

Autto, Janne \& Nygård, Mikael (2015) Johdanto: Mitä on hyvinvointivaltion kulttuurintutkimus? Teoksessa Janne Autto \& Mikael Nygård (toim.) Hyvinvointivaltion kulttuurintutkimus. Rovaniemi: Lapin yliopistokustannus, 8-41.

Avioliittolakikomitean mietintö 1972: A 21. Helsinki: Oikeusministeriö.

Besnard, Philippe (1993) Anomie and fatalism in Durkheim's theory of regulation. Teoksessa Stephen Turner (toim.) Émile Durkheim: Sociologist and Moralist. London: Routledge. https://doi. org/10.4324/9780203168257_chapter_7

Bildjuschkin, Katriina (2018) Eropalveluilla kohti sovinnollisuutta. THL Työpaperi 40/2018. Helsinki: Terveyden ja hyvinvoinnin laitos.

Bradley, David (1996) Family law and political culture: Scandinavian laws in comparative perspective. London: Sweet \& Maxwell.

Burgess, Ernest \& Locke, Harvey (1945) The family. From institution to companionship. New York: American Book Company.

Castrén, Anna-Maija \& Tuomaala Vaula \& Neuvonen Samuli (2017) Avioliittoperheen tuolla puolen: Vastasyntynei- 
den perheet Helsingissä. Tutkimuksia 3/2017. Helsinki: Helsingin kaupunki, kaupunginkanslia, kaupunkitutkimus ja -tilastot. https://www.hel.fi/hel2/tietokeskus/julkaisut/pdf/17_06_19_Tutkimuksia_3_Castren_Tuomaala_Neuvonen.pdf

Durkheim, Émile (1906) Le divorce par consentement mutuel. Une édition électronique réalisée à partir d`un texte d'Émile Durkheim (1906), Le divorce par consentement mutual. Extrait de la Revue bleue, 1906, 44, (5), pp. 549 à 554. Reproduit in Émile Durkheim, Textes. 2. Religion, morale, anomie, pp. 181 à 194. Paris: Éditions de Minuit, 1975, 508 pp. Collection: Le sens commun. http:// classiques.uqac.ca/classiques/Durkheim emile/textes_2/textes_2_05/divorce consentement.pdf Luettu 27.12.2018 https://doi.org/10.1522/cla.due.div

Eläkeliitto (2019) Sopeutumisvalmennus eronneille. https://www.elakeliitto.fi/ sopeutumisvalmennus-eronneille Luettu 31.10 .2019$.

EOA 2059/2/03 Eduskunnan oikeusasiamiehen päätös (2004) Havaintoja vanhempien välisiin ristiriitoihin tarjolla olevista sovittelu- ja neuvontapalveluista lapsiin liittyvissä kysymyksissä.

Forsberg, Hannele \& Kääriäinen, Aino \& Ritala-Koskinen, Aino (2018) Children's Residence in Divorce Disputes - Examination of Social Workers' Court Reports. Journal of Social Welfare and Family Law 39 (1), 21-36.

Forsberg, Hannele \& Nätkin, Ritva (toim.) (2004) Perhe murroksessa. Helsinki: Gaudeamus.

Goode, William (1961) Family disorganization. Teoksessa Robert Merton \& Robert Nisbet (toim.) Contemporary Social Problems: An introduction to the sociology of deviant behavior and social disorganization. New York: Hardcourt, Brace \& World, 478-552.

Haavisto, Vaula \& Bergman-Pyykkönen, Marina \& Karvinen-Niinikoski, Synnöve (2014) Perheasioiden sovittelun uudet tuulet: havaintoja, mallinnuksia ja arvioita FASPER-hankkeen pohjalta. Helsinki: Suomen sovittelufoorumi.

Hemminki, Arja (2010) Kertomuksia avioerosta ja parisuhteen päättymisestä. Suo- malainen eropuhe pohjalaisten kirjoituksissa ja naistenlehdissä. Jyväskylä Studies in Education, Psychology and Social Research 399. Jyväskylä: Jyväskylän yliopisto.

Härkönen, Juho (2014) Divorce: Trends, Patterns, Causes, and Consequences. Teoksessa Judith Treas, Jacqueline Scott \& Martin Richards (toim.) The Wiley Blackwell Companion to the Sociology of Families. West Sussex: John Wiley \& Sons, 303-322.

Ilmonen, Kari \& Juurikko, Annika \& Pekkarinen, Sanna (2018) Etuudet ja palvelut lasten vuoroasumistilanteissa - lasten vuoroasumista selvittäneen työryhmän loppuraportti. Sosiaali- ja terveysministeriön raportteja ja muistioita 18. Helsinki: Sosiaali- ja terveysministeriö. http:// urn.fi/URN:ISBN:978-952-00-3929-5. Luettu 26.8.2019. https://doi. org/10.26530/oapen_622450

Jaakkola, Risto (1975) Lausunnot avioliittolakikomitean 1. mietinnöstä. Lainvalmisteluosasto 3/75. Helsinki: Oikeusministeriö.

Jaakkola, Risto (1984) Om samboende i Finland på 1930-talet. Historisk Tidskrift för Finland 69 (3), 301-317.

Jaakkola, Risto (1989) Avoliitot ja ajan henki 1930-luvulla. Teoksessa Pekka Kosonen \& Anneli Levo-Kivirikko (toim.) Vapaus, veljeys ja vallankäyttö. Helsinki: Helsingin yliopisto, 111-126.

Jallinoja, Riitta (1983) Suomalaisen naisasialiikkeen taistelukaudet. Helsinki: WSOY.

Jallinoja, Riitta (1984) Perhekäsityksistä perhettä koskeviin ratkaisuihin. Teoksessa Elina Haavio-Mannila, Riitta Jallinoja \& Harriet Strandell (toim.) Perhe, työ ja tunteet. Porvoo:WSOY, 37-110.

Jalovaara, Marika (2007) The effects of marriage partners' socio-economic positions on the risk of divorce in Finland. Finnish Yearbook of Populations Research XLIII 2007: Supplement. Helsinki:The Population Research Institute.

James, Allison \& James, Adrian (2004) Constructing Childhood: Theory, policy and social practice. Basingstoke: Palgrave Macmillan.

James, Allison \& James, Adrian (2008) Key concepts in childhood studies. Los Ange- 
les, London, New Delhi, Singapore: Sage. Jousimaa, Kaarina (1983) Jokainen lapsi on pelastettava elämälle: Avioton äiti ja lapsi suomalaisessa yhteiskunnassa. Ensi Kotien Liiton Julkaisu 3. Helsinki: Ensi Kotien Liitto ry.

Kalavainen, Susanna (toim.) (2004) Valvotut tapaamiset lapsen turvana. Helsinki: Ensi- ja turvakotien liitto.

Kestilä, Laura \& Paananen, Reija \& Väisänen, Antti \& Muuri, Anu \& Merikukka, Marko \& Heino, Tarja \& Gissler, Mika (2012) Kodin ulkopuolelle sijoittamisen riskitekijät. Rekisteripohjainen seurantatutkimus Suomessa vuonna 1987 syntyneistä. Yhteiskuntapolitiikka 77 (1), 34-52.

Key, Ellen (1903) Kärleken ock äktenskap. Stockholm: Albert Bonniers Förlag.

Kulhia, Ali (2012) Uutta, vanhaa ja lainattua. Tampereen kaupunkilähetyksen kristillissosiaalisen työn asemoituminen hyvinvointivaltion rakentumisessa vuosina 1939-1973. Helsinki: Unigrafia.

Kurki-Suonio, Kirsti (1999) Äidin hoivasta yhteishuoltoon: Lapsen edun muuttuvat oikeudelliset tulkinnat. Suomalaisen Lakimiesyhdistyksen julkaisuja sarja A: 222. Helsinki: Suomalainen lakimiesyhdistys.

Lamanna, Mary Ann (2002) Emile Durkheim on the family. London: Sage Publications.

Lastensuojelun käsikirja 2018. https://thl. $\mathrm{fi} / \mathrm{fi} /$ web/lastensuojelun-kasikirja. Luettu 18.12.2018.

Levin, Irene (2004) Norwegian children's perception of divorce. One or more phenomenon? Teoksessa Hannele Forsberg \& Anja-Riitta Lahikainen (toim.) (2004) What's new? Nordic-Baltic Perspectives on Family, Childhood and Social Problems. Family and Childhood Research Unit Net Series No 1. Tampere:Tampere University Press.

Litmala, Marjukka (2001) Avioeroprosessin piirteet. Tutkimus helsinkiläisistä avioeroista vuonna 2000. Oikeuspoliittisen tutkimuslaitoksen tutkimustiedonantoja 55. Helsinki: Oikeuspoliittinen tutkimuslaitos.

Lähteenmäki, Maria (2000) Vuosisadan naisliike. Naiset ja sosiaalidemokratia 1900-luvun Suomessa. Helsinki: Sosiaalidemokraattiset Naiset.
Mahkonen, Sami (1980) Avioero:Tutkimus avioliittolain erosäännösten taustasta ja tarkoituksesta. Suomalaisen Lakimiesyhdistyksen julkaisuja sarja A: 149. Helsinki: Suomalainen Lakimiesyhdistys.

Maksimainen, Jaana (2010) Parisuhde ja ero: Sosiologinen analyysi terapeuttisesta ymmärryksestä. Sosiaalitieteiden laitoksen julkaisuja 2010:3. Helsinki: Helsingin yliopisto.

Maksimainen, Jaana (2014) Avioliiton pelastamisesta parisuhteen hoitamiseen: muodosta sisältöön. Sosiologia 51 (2), 123-138.

Miessakit (2018) Erosta elossa. https:// www.miessakit.fi/fi/toimintamuodot/ erosta_elossa. Luettu 7.12.2018.

Monahan, Thomas (1957) Family status and the delinquent child: A reappraisal and some new findings. Social Forces 35 (3), 250-258. https://doi. org $/ 10.2307 / 2573509$

MLL Tampereen osaston Eron ensiapupiste (2018). https://tampere.mll.fi/eroperheiden-kohtaamispaikka/eron-ensiapupiste/. Luettu 7.12.2018.

Mäenpää, Elina (2015) Socio-economic homogamy and its effects on the stability of cohabiting unions. Finnish Yearbook of Population Research L2015 Supplement. Helsinki: The Population Research Institute.

Nieminen, Armas (1951) Taistelu sukupuolimoraalista: avioliitto- ja seksuaalikysymyksiä suomalaisen hengenelämän ja yhteiskunnan murroksessa sääty-yhteiskunnan ajoilta 1910-luvulle. Helsinki: WSOY.

Nieminen, Armas (1956) Muuttuva yhteiskunta ja perheen tehtävät. Sosiaalityöntekijä asiakkaansa auttajana, henkilökohtaisen huollon kansallisen seminaarin pöytäkirjat. Kiljava 3.1.-14.1. 1955, Pieksämäki 1956, 21-31.

Nieminen, Armas (1993) Suomalaisen aviorakkauden ja seksuaalisuuden historia. Avioliitto- ja seksuaalikysymyksiä suomalaisen hengenelämän ja yhteiskunnan murroksessa sääty-yhteiskunnan ajoilta nykypäivään. Väestöntutkimuksen julkaisusarja D, nro 27/1993. Helsinki: Väestöntutkimuslaitos,Väestöliitto.

Nikander, Timo (1996) Perheiden muodostuminen ja hajoaminen. Väestö 1996: 
17. Helsinki: Tilastokeskus.

Nikander, Timo (1997) Katsaus viime vuosien perheellistymiseen Suomessa. Hyvinvointikatsaus 1997 (2), 15-20.

Näre, Sari (2008) "Kuin viimeistä päivää" - sota-ajan sukupuolikulttuuri ja seksuaalinen väkivalta. Teoksessa Sari Näre \& Jenni Kirves (toim.) Ruma sota: talvija jatkosodan vaiettu historia. Helsinki: Johnny Kniga Publishing, 335-380.

Nätkin, Ritva (2004) Moninaiset perhemuodot ja lapsen hyvä. Teoksessa Hannele Forsberg \& Ritva Nätkin (toim.) Perhe murroksessa. Helsinki: Gaudeamus, 16-38

Paajanen, Pirjo (2003) Parisuhde koetuksella. Käsityksiä parisuhteesta ja sen purkautumisesta. Perhebarometri 2003. Väestöntutkimuslaitos E 17. Helsinki: Väestöliitto.

Panttila, Raija (2005) Kahden kodin lapsuus: Katsaus lapsen vuorottelevan asumisen kirjallisuuteen ja toteutukseen. SOCCAn ja Heikki Waris -instituutin julkaisusarja 1/2005. Helsinki: SOCCA ja Heikki Waris -instituutti.

Pitkänen, Kari (1986) Marital dissolution in Finland:Towards a long-term perspective. Yearbook of Population Research in Finland 24, 60-71.

Pitkänen, Kari \& Jalovaara, Marika (2007) Perheet ja perheenmuodostus. Teoksessa Seppo Koskinen, Tuija Martelin, IrmaLeena Notkola, Veijo Notkola, Kari Pitkänen, Marika Jalovaara, Elina Mäenpää, Anne Ruokolainen, Markku Ryynänen \& Ismo Söderling (toim.) Suomen väestö. Helsinki: Gaudeamus, 115-168.

Pylkkänen, Anu (2012) Vaihtoehto avioliitolle. Seksuaalisuudesta yhteistalouden sääntelyyn. Tampere:Vastapaino.

Pääministeri Antti Rinteen hallitusohjelma (2019) Osallistava ja osaava Suomi - sosiaalisesti, taloudellisesti ja ekologisesti kestävä yhteiskunta. Valtioneuvoston julkaisuja 2019/23. Helsinki:Valtioneuvosto.

Pääministeri Juha Sipilän hallituksen strateginen ohjelma (2015) Valtioneuvoston kanslia. Hallituksen julkaisusarja 10/2015. Helsinki:Valtioneuvosto.

Pääministeri Jyrki Kataisen hallituksen ohjelma (2011). Hallitusohjelma.Valtioneuvoston kanslia. Hallituksen julkaisusarja 1/2011. Helsinki:Valtioneuvosto.
Ristikari, Tiina \& Keski-Säntti, Markus \& Sutela, Elina \& Haapakorva, Pasi \& Kiilakoski, Tomi \& Pekkarinen, Elina \& Kääriälä, Antti \& Aaltonen, Mikko \& Huotari, Tiina \& Merikukka, Marko \& Salo, Jarmo \& Juutinen, Aapo \& Pesonen-Smith, Anna \& Gissler, Mika (2018) Suomi lasten kasvuympäristönä. Kahdeksantoista vuoden seuranta vuonna 1997 syntyneistä.THL:n raportti 7/2018. Helsinki:THL \& Nuorisotutkimusseura. Ronfani, Paola (2003) Family law in Europe. Teoksessa David Kertzer \& Marzio Barbagli (toim.) Family life in the twentieth century. New Haven:Yale University Press, 113-151.

Satka, Mirja \& Moilanen, Johanna \& Kiili, Johanna (2002) Suomalaisen lapsipolitiikan mutkainen tie. Yhteiskuntapolitiikka 67 (3), 245-259.

Smart, Carol (2000) Divorce and changing family practices in post-traditional society. Moral decline or changes to moral practices. Family Matters 56, 10-19.

Smart, Carol \& Neale, Bren (1999) Family Fragments. Cambridge: Polity.

Suomen virallinen tilasto (SVT): Perheet (2013) Helsinki: Tilastokeskus. http://www.stat.fi/til/perh/2013/02/ perh_2013_02_2014-11-21_tie_001_ fi.html Luettu 27.6.2018.

Suomen virallinen tilasto (SVT): Perheet (2017) Helsinki: Tilastokeskus http://www.stat.fi/til/perh/2017/02/ perh_2017_02_2018-12-05_tie_001_ fi.html Luettu 18.12.2018.

Suomen virallinen tilasto (SVT): Siviilisāädyn muutokset (2016) Liitetaulukko 1. Avioliittojen ja avioerojen määrä vuosina 1965-2016. Helsinki: Tilastokeskus. http://www.stat.fi/til/ssaaty/2016/ssaaty_2016_2017-04-20_tau_001_fi.html Luettu 23.4.2018.

Suomen virallinen tilasto (SVT): Väestö 2017 (2017). Siviilisäädyn muutokset 2016 Helsinki: Tilastokeskus. https:// www.stat.fi/til/ssaaty/2016/ssaaty_2016_2017-04-20_tie_001_fi.html Luettu 2.10.2019.

Taskinen, Sirpa (toim.) (1993) Itke vain sydämein. Tausta-aineistoa perheasioiden sovitteluun. Raportteja 84. Helsinki: Stakes.

Taskinen, Sirpa (toim.) (1994) "En ole 
katkera, mutta kuitenkin..." Avioerosta selviytyminen ja perheasioiden sovittelu. Raportteja 166. Helsinki: Stakes.

Théry, Irene (1986) The interest of the child and the regulations of the post-divorce family. International Journal of the Sociology of Law 14, 341-358.

Tilastokeskus: Avioeronneisuus sukupuolen ja iän mukaan 1990-2017. PX-Webtietokannat. Luettu 18.12.2018.

Vanhemmuussuunnitelmasta tukea eron jälkeiseen vanhemmuuteen (2018) Helsinki: Sosiaali- ja terveysministeriö. https://stm.fi/vanhemmuussuunnitelma Luettu 7.12.2018.

Williams, Raymond (1995) The sociology of culture. Chicago: The University of Chicago Press.

Yesilova Katja (2009) Ydinperheen politiikka. Helsinki: Gaudeamus.

\section{LAINSÄÄDÄNTÖ}

(HTTP://WWW.FINLEX.FI/FI/LAKI/)

Avioliittolaki 234/1929.

Isyyslaki 700/1975.

Laki avioliittolain muuttamisesta 342/1963.

Laki avioliittolain muuttamisesta 681/1948.

Laki avioliittolain muuttamisesta 705/1975.

Laki avioliittolain muuttamisesta 411/1987.

Laki lapsen elatuksesta 704/1975.

Laki lapsen huollosta ja tapaamisoikeudesta 361/1983.

Laki lapsen huollosta ja tapaamisoikeudesta annetun lain 3 S:n muuttamisesta 190/2019.

Perintökaari 710/1975.

Sosiaalihuoltolaki 1301/2014. 